\title{
Current and Future Perspectives for Improving Ovarian Tissue Cryopreservation and Transplantation Outcomes for Cancer Patients
}

\author{
Sanghoon Lee ${ }^{1,2}$ (D) $\cdot$ Sinan Ozkavukcu ${ }^{3} \cdot$ Seung-Yup $\mathrm{Ku}^{4}$ \\ Received: 25 September 2020 / Accepted: 21 February 2021 / Published online: 31 March 2021 \\ (C) The Author(s) 2021
}

\begin{abstract}
Although advances in cancer treatment and early diagnosis have significantly improved cancer survival rates, cancer therapies can cause serious side effects, including ovarian failure and infertility, in women of reproductive age. Infertility following cancer treatment can have significant adverse effects on the quality of life. However, established methods for fertility preservation, including embryo or oocyte cryopreservation, are not always suitable for female cancer patients because of complicated individual conditions and treatment methods. Ovarian tissue cryopreservation and transplantation is a promising option for fertility preservation in pre-pubertal girls and adult patients with cancer who require immediate treatment, or who are not eligible to undergo ovarian stimulation. This review introduces various methods and strategies to improve ovarian tissue cryopreservation and transplantation outcomes, to help patients and clinicians choose the best option when considering the potential complexity of a patient's situation. Effective multidisciplinary oncofertility strategies, involving the inclusion of a highly skilled and experienced oncofertility team that considers cryopreservation methods, thawing processes and devices, surgical procedures for transplantation, and advances in technologies, are necessary to provide high-quality care to a cancer patient.
\end{abstract}

Keywords Fertility preservation · Ovarian freezing · Autologous transplantation · Cancer treatment · Oncofertility $\cdot$ Primary ovarian insufficiency

\section{Introduction}

A large number of young women of reproductive age are diagnosed with cancer each year. In 2018, approximately 8.6 million women worldwide struggled with a malignancy $[1,2]$; although most of these women were of advanced age, $10 \%$ were under the age of 45 [3]. In 2020, an estimated 89,500

Sanghoon Lee

mdleesh@gmil.com

1 Moores Cancer Center, University of California San Diego, San Diego, CA, USA

2 Department of Obstetrics and Gynecology, Korea University College of Medicine, 73, Inchon-ro, Seongbuk-gu, Seoul 02841, Republic of Korea

3 Center for Assisted Reproduction, Department of Obstetrics and Gynecology, Ankara University Faculty of Medicine, Ankara, Turkey

4 Department of Obstetrics and Gynecology, Seoul National University College of Medicine, Seoul, Republic of Korea cancer cases and 9270 cancer deaths occurred among adolescents and young adults aged 15 to 39 years in the USA [4]. Early diagnosis and follow-up methodologies, especially chemotherapy and radiotherapy, have increased the survival rates of these patients [1]. However, both of these treatments can cause loss of ovarian function and primary ovarian insufficiency (POI) due to follicular depletion $[5,6]$, with alkylating agents, such as cyclophosphamide, known to be severely gonadotoxic [7]. In addition, ovarian surgeries to treat endometriosis or other benign ovarian tumors, and the cytotoxic agents used to treat some benign diseases, have also been associated with fertility loss $[8,9]$.

In recent years, there has been a sharp increase in the number of women diagnosed with cancer seeking to preserve their future fertility [10]. Embryo and oocyte cryopreservation are well-established methods of fertility preservation. Early referral to reproductive specialists is crucial for patients of prepubertal and childbearing age with cancer [11-13]. Ovarian tissue cryopreservation and transplantation (OTC-T) is an essential option for fertility preservation, particularly for postpubertal women with cancer who require immediate chemotherapy or who are not eligible for ovarian stimulation; 
however, for pre-pubertal female patients, it is the gold standard in fertility preservation [14].

A recent study evaluating 364 women who had undergone ovarian tissue cryopreservation (OTC) showed that more than 95\% had experienced long-term restoration of ovarian function [15]. Since 2004, when the first human live-birth relating to ovarian cortex auto-transplantation was recorded, technique improvements have resulted in an estimated live birth rate between 35 and $40 \%$ [16]. Although the exact number of OTC, or OTC-T cases is unknown, and given that the effectiveness of the procedure cannot be calculated definitively, it is estimated that, worldwide, more than 130 children, with a $30 \%$ conception rate, have been conceived following ovarian tissue transplantation (OTT) $[10,15,17]$. OTC and retransplantation were previously considered "experimental"; however, following heavy debate, and given the increasing number of reported live births and experience in surgical and laboratory techniques, it is now registered by major societies of reproduction as an acceptable procedure for fertility preservation $[18,19]$. A key drawback of this procedure is the risk of malignant contamination on the ovarian graft following auto-transplantation. To date, not a single case of relapse due to malignant cell debris in transplanted tissue has been reported in humans; however, some studies have indicated an increased risk of hematological malignancy relapse in xenotransplantation models involving only immunosuppressed animals [20, 21].

Recovery of endocrine function and fertility through OTC$\mathrm{T}$ may improve the quality of life of women of reproductive age following cancer survival [14]. This review discusses novel methods and strategies to improve the outcomes of OTC-T; thus, allowing physicians to choose the most appropriate fertility preservation technique for their patients.

\section{Ovarian Toxicity Caused by Cancer Treatment}

Although advances in chemotherapy and radiation therapy have greatly improved the effects of cancer treatment and the survival rate of cancer patients, gonadal damage remains a serious complication. The incidence of chemotherapy-induced amenorrhea reportedly ranges from 53 to $89 \%$ in patients with breast cancer [22]. Iatrogenic POI caused by conventional chemotherapy treatments depends on the type, dosage, and duration of chemotherapy drugs, as well as the age of the patient [23]. Primordial follicles decline with increasing age, with a higher risk of gonadal damage and infertility in older patients. Since most cancer patients are treated with multiple chemotherapy drugs, it is difficult to assess the extent of reproductive damage caused by each specific agent $[24,25]$.

Anticancer drugs primarily exert their gonadotoxic effects through the direct induction of DNA double-stranded breaks, resulting in the activation of apoptosis and/or autophagyrelated pathways [26-29]. Second, anticancer drugs can indirectly cause primordial follicle loss via microvascular and stromal damage through ischemia, necrosis, or inflammation $[26,28,30]$. Third, studies have shown that anticancer drugs can activate the PI3K/AKT/FOXO3a pathway, leading to follicular loss via the activation of primordial follicles [29, $31,32]$. Follicle activation and ovarian reserve burn-out are also potentially important mechanisms of follicle loss posttransplantation of OT grafts [33].

Primordial follicles are very sensitive to radiation, and the degree of damage to the ovaries depends on the total dose, field of treatment, fractionation schedule, and age at the time of treatment [34]. Radiotherapy-induced amenorrhea can occur when pelvic or whole abdominal areas are exposed to a radiation dose $\geq 6$ Gy in adult women, $\geq 10$ Gy in postpubertal girls, and $\geq 15$ Gy in prepubertal girls [34-36].

\section{Comparison of OTC Techniques: Slow Freezing vs Vitrification}

The age of the patient, presence of a partner, treatment method, and possibility of treatment delay should all be considered when considering fertility preservation. Cryopreservation of both embryos and oocytes requires a period of approximately 10-14 days from the onset of menstruation for ovarian stimulation; however, since all oocytes and embryos are frozen at the end of a cycle, random start protocols may be used for controlled ovarian stimulation. Although embryo cryopreservation was considered to be the best-established fertility preservation technique worldwide, in jurisdictions where each partner has equal legal rights over an embryo, their utilization is subject to each parent's consent. Furthermore, divorce rates are known to increase in families where one partner is receiving cancer treatment, especially in women [37]. As such, embryo cryopreservation can become an option that limits the freedom of a divorced woman seeking to reconsider her fertility preferences in the future, as accessing the cryopreserved embryos is dependent on her ex-partner's consent. Since oocyte cryopreservation is considered a standard procedure in modern assisted reproductive technologies, it should be offered as the first option for post-pubertal women applying for fertility preservation $[34,36]$.

As OTC has the advantage of not requiring a sperm donor or ovarian stimulation, it is the only possible choice for prepubertal girls and patients who cannot postpone cancer treatment for ovarian stimulation. In contrast to freezing individual oocytes or embryos, OTC can effectively preserve hundreds of primordial follicles simultaneously [14]. This technique can be performed using slow freezing or vitrification. Using the slow freezing method, OT is frozen slowly in a controlled manner down to $-140^{\circ} \mathrm{C}$, and then stored at $-196^{\circ} \mathrm{C}$, in liquid nitrogen. Using this technique, no serious tissue deformation is observed; however, there is a risk of ice crystal formation causing mechanical damage to the cells [38]. In contrast, 
vitrification involves instantaneous solidification of the solution, with viscosity maintained using a high concentration of cryoprotectant agents [16]. Notably, this technique has a low risk of ice crystal formation, reduced handling time, and inexpensive equipment.

A recent systematic review and meta-analysis of 14 experimental studies compared vitrification with slow freezing for OTC [39]. In pooled analyses, no significant difference in follicular density or proportion of intact primordial follicles was observed between the two methods; however, vitrification was associated with significantly less damage to follicular DNA and better preservation of stromal cells. This review also emphasized the diversity of the vitrification protocols used in the studies, thereby highlighting the lack of standardization [39]. Some studies suggested that regardless of the freezing method, type of follicle, or species involved in an experiment, vitrification resulted in greater damage to the follicles than slow freezing [40]. In addition, the ability of frozen thawed cortical tissue to produce anti-Müllerian hormone (AMH) in tissue cultures was superior after slow freezing [41]. According to previous studies, only a small percentage of children have been conceived following transplantation of vitrified-warmed OT [15, 42-44]. Furthermore, for vitrification, the volume of the sample must be reduced in order to reach the maximum rate of heat exchange. Considering the size of OT biopsies, obtaining very small fragments may hinder long-term cryo-storage methods and jeopardize surgical procedures during re-transplantation. Even minimally fragmented ovarian pieces are thousands of times larger than the volume of an oocyte. Practically, smaller fragments increase the number of pieces to be vitrified, and an operator must conduct each step, namely, equilibration, loading, and vitrification, individually for each fragment, each of which requires an optimum, yet limited, duration in the highly concentrated and toxic equilibrium and vitrification media [45]. This method significantly extends the total duration of the freezing process, thereby increasing the risk of toxicity due to a high CPA concentration. Slow freezing is currently considered a more appropriate method for OTC than vitrification [46]. Considering the limited comparisons between the effects of vitrification and slow freezing on OT, further studies investigating the efficiency of vitrification are required.

\section{Potential Considerations for Improving the Outcomes of OTC}

Considering that majority of pregnant women reported in the literature have been under the age of 30 at the time of cryopreservation, patient age is a key factor for predicting its success. Thirty-five years of age is generally considered the upper limit for OTC, as primordial follicles are primarily preserved during this procedure, and their number decreases significantly with age [47]. AMH levels and antral follicle count can be used to test the ovarian reserve; patients should be informed about their chances of future pregnancy prior to fertility preservation [48]. Recently, many suggestions regarding the criteria for selecting patients for ovarian cryopreservation have been proposed [49]; however, some criteria require ethical consideration.

\section{Cryoprotectants}

Multiple cryoprotectants are used for OTC, with several of those used for slow freezing human OT been previously studied, including glycerol, ethylene glycol, dimethyl sulfoxide (DMSO), and propanediol. Follicle survival was evaluated after thawing fragments of frozen ovarian cortical tissue with cryoprotectants. The highest and lowest follicle survival rates were obtained with ethylene glycol and glycerol, respectively [50]. Although the most commonly used cryoprotectants are ethylene glycol and DMSO, propylene glycol is also used by some centers [51-53]. One vitrification protocol used $20 \%$ DMSO and $20 \%$ ethylene glycol, while another used $10 \%$ DMSO and $26 \%$ ethylene glycol, resulting in a higher proportion of primordial follicles [54]. DMSO, a low molecular weight organic molecule, rapidly penetrates cell membranes and further reduces intracellular ice nucleation, which is generally combined with non-penetrable sucrose [55]. Although used frequently in vitrification protocols, DMSO is usually combined with ethylene glycol and propanediol due to toxicity concerns $[56,57]$. DMSO has recently been extracted from some oocyte/embryo vitrification solutions, in which case, a combination of ethylene glycol and propanediol is used [58-60]. Although sucrose is the most commonly used nonpenetrating agent in freezing and thawing processes, trehalose has been used as its alternative in recent years [61]. Cryopreservation followed by transplantation is affected by the clinical environment; most studies have evaluated the efficiency of OTC after warming or in vitro culture [54]. Further research is needed to determine the most efficient protocol for vessel formation and cell proliferation after OTC-T.

\section{Anti-apoptotic Agents}

Other key factors that ensure the survival of OTC-T are revascularization and apoptosis prevention. Several studies have reported that increased apoptotic follicles were observed shortly after OTT [62-64]. Sphingosine-1-phosphate (S1P), an anti-apoptotic substance in oocytes $[65,66]$, and ceramide play central roles in apoptosis. S1P inhibits ceramide, which induces cell cycle arrest and promotes apoptosis [67]. S1P has been shown to protect vitrified ovarian grafts from ischemic reperfusion injury and promote neo-angiogenesis in ovarian transplants $[68,69]$. However, we found that S1P did not help preserve, or increase the proliferation of, follicles, nor did it protect against DNA damage during the freezing-thawing 
process (unpublished results). In contrast, Z-VAD-FMK administration improved follicle preservation and follicular cell proliferation, also preventing DNA damage during the freezing-thawing process [70]. Although these substances are known to contribute to follicle protection by reducing apoptosis in transplanted OT, their routine use is not possible in contemporary practice; further investigation is warranted.

\section{$\mathrm{AMH}$}

$\mathrm{AMH}$, another promising agent for fertility preservation, belongs to the transforming growth factor (TGF)-beta family of proteins, and plays a key role in controlling sexual differentiation and follicular genesis. Although serum AMH has long been used in reproductive biology as a key marker of ovarian reserve, it has also recently been investigated as a protective agent $[71,72]$. Administration of recombinant AMH inhibits the initiation of primordial follicle recruitment [73, 74]; recently, co-administration of AMH and chemotherapy agents has been shown to protect the ovarian reserve by suppressing primordial follicle recruitment [75].

One challenge in OTC is mass primordial follicle loss in the OT immediately after transplantation, resulting in the shorter longevity of transplanted ovarian function [64]. Using AMH to inhibit primordial follicle recruitment has proven useful in reducing this initial follicular loss; cotransplantation of the graft with exogenous endothelial cells engineered to produce AMH in situ significantly decreased primordial follicle loss in human xenotransplants [76, 77]. These studies suggest that it may be possible to protect the ovarian reserve from gonadotoxic drugs; further human clinical trials are warranted [78].

\section{Slush Nitrogen (SN)}

Liquid nitrogen is limited in its efficiency as a coolant due to the Leidenfrost effect, namely, it boils immediately upon contact with a warmer object, forming insulating nitrogen gas. Recently, SN has been proposed as a new agent for increasing the cooling rate, avoiding the Leidenfrost effect, and facilitating the use of low concentrations, or reduced exposure times, of cryopreservation agents (CPAs) [79]. Reportedly, fresh and $\mathrm{SN}$-vitrified mouse oocytes develop to the same blastocyst stage and produce similar proportions of healthy offspring. SN has improved the vitrification outcomes of both human oocytes and OT, including recovering healthy oocytes, granulosa cells, and stromal cells via an increased cooling rate [80-83]. At the tissue level, where larger volumes of samples are prepared, faster cooling rates are required to maintain vitrification; $\mathrm{SN}$ can be used as an alternative method through which to rapidly reduce the temperature.

\section{Laser-assisted Thawing}

Successful vitrification depends largely on the rate of warming, rather than the type and concentration of cryoprotective agent, and successful osmotic dehydration before cooling, to avoid the re-crystallization of water in the thawing cycle, when very rapid warming is essential. A recent study reported high oocyte and embryo survival rates following vitrification, without cryoprotectant permeation after thawing via ultra-fast warming using an infrared laser pulse [84]. Another study used a laser beam to dehydrate the blastocoel before vitrification, finding significant improvements in clinical outcomes due to decreased ice recrystallization [85].

\section{Cryopreservation as a Method to Reduce the Risk of Cancer Cell Reimplantation}

OTC may be possible for patients with aggressive cancer who require immediate chemotherapy; however, contaminating OT with malignant cells is a major concern when considering this technique [86, 87]. A small number of malignant cells may be present in OT, with relapses following transplantation having been observed in both human and mouse hematologic malignant tumor models $[88,89]$. Although no case in which a relapse occurred following OT auto-transplantation has been reported, animal studies have shown that hematological malignancies can settle in the ovary, potentially causing relapses or metastases under appropriate conditions. These results were predominantly derived from xenografting studies using immunosuppressed mice. Malignant cells in grafted OT may never undergo activation or may be eliminated due to the patient's newly formed immune system following bone marrow transplantation. Therefore, although the experimental xenograft model highlights the importance of remaining alert, it may be inadequate for demonstrating the accurate clinical situation. Therefore, despite two recent publications reporting successful fertility preservation after ovarian transplantation in acute leukemia, this technique may not be suitable for women with ovarian or hematologic malignancies [90, 91]. In the future, reproductive function or fertility may be preserved in these patients via the in vitro maturation (IVM) of oocytes and artificial ovary techniques [87]. Some studies have proposed that even if ovarian function is impaired, OT can be cryopreserved after undergoing an initial chemotherapy process to reduce the risk of cancer contamination [21, 92]. Reportedly, in vitro incubation with YAP/TAZ inhibitor verteporfin prior to auto-transplantation eliminates rhabdomyosarcoma and leukemia cells that have metastasized to the OT [93]. These studies strongly recommend the wide screening of tissue samples containing fragments intended for transplantation using both histological examinations and possible molecular biomarkers. Polymerase chain reaction, flow cytometry, or immune labeling should be used to rule out tumor contamination 
in transplanted tissues, especially in malignancies prone to ovarian metastasis $[94,95]$.

\section{Surgical Considerations to Improve the Outcomes of OTT}

\section{Introduction to Surgical Techniques}

Prior to receiving cancer treatment, OTC-T in women diagnosed with cancer is an effective option for preserving fertility and restoring reproductive endocrine function [96]. Various surgical techniques have been introduced to transplant human OT following cryopreservation, including open laparotomy, mini-laparotomy, laparoscopy, and robot-assisted transplantation [97]. The first ovarian transplantation with cryopreserved OT was performed in 1999 [98, 99]. In 2004, the first successful live birth was reported following the transplantation of OT that was cryopreserved using the slow freezing method [100]. In recent years, the number of pregnancies and births following cryopreserved OTT using different surgical techniques has steadily increased [17]. Robot-assisted transplantation may have several advantages over laparoscopic transplantation, including precision, more delicate graft handling, and reduced time from tissue thawing to transplantation [101]. Physicians should select the most suitable technique through which to maximize OTT outcomes by considering their own clinical experience and animal experiments.

As the decision to perform ovarian cryopreservation is often made clinically when patients have limited time before starting chemotherapy, a laparoscopic approach, involving minimally invasive surgery, is a very useful technique. One of the most important advantages of laparoscopic surgery is that patients recover very quickly, enabling them to promptly start chemotherapy [97]. In particular, a single-port laparoscopy is widely used in surgical gynecology and is associated with a low rate of complications following OT extraction [102].

\section{OT Extraction and Surgical Tools}

Various pinions exist on the volume of tissue that should be extracted when collecting OT. Large samples have the advantage of allowing for repeat transplantations, which potentially maintains reproductive and endocrine ovarian function longer. Different strategies may be considered depending on a patient's situation. If aggressive chemotherapy with alkylating agents, pelvic irradiation, or high-dose chemotherapy is necessary prior to bone marrow transplantation, large amounts of OT should be removed before ovarian failure. However, keeping more OT in situ may be a more desirable strategy when less toxic chemotherapy is scheduled. For OT excision, ovarian cortical biopsy, or partial or complete oophorectomy, may be performed [103]. According to the von Wolff group, 50\% resection of the ovary may be sufficient for cryopreservation
[104]. Following cancer treatment completion, frozen OT can be prepared and grafted onto the surface of the remaining ovary or the pelvic peritoneum [105]. Although frozenthawed OT is orthotopically transplanted in most cases, heterotopic transplantation into the subcutaneous space of the abdominal wall or the forearm can be considered in unavoidable circumstances [106, 107].

Generally, scissors or a scalpel without coagulation are recommended to use when extracting and transplanting OT, as electrocoagulation may damage OT and reduce ovarian reserve $[108,109]$. Using sutures or fibrin adhesives on the ovarian surface may be considered during tissue transplantation after weighing the potential risk of secondary bleeding. In pre-pubertal patients whose treatment regime contains highly toxic interventions, such as alkylating agents or radiotherapy, unilateral ovarian extraction should be considered following parental consultation. As the organ size is significantly smaller in this age group, optimal fertility preservation can be achieved using one whole ovary.

\section{Potential Sites for Transplantation}

Potential sites for transplanting frozen-thawed OT are (i) on the remaining menopausal ovary [110], (ii) into the ovarian ligament [111], (iii) a pre-prepared peritoneal pocket [91], or (iv) heterotopic transplantation [107]. Potential advantages of an ovary as a transplantation site include that the tissue was originally collected from the same site; hence, transplanted samples could easily be located and revived. However, the risk of bleeding and the possibility of ovarian trauma due to sutures must be considered; the peritoneal pocket may be another option if the remaining OT is not sufficient to receive the transplant. Although heterotopic transplantation has the advantage of not requiring abdominal surgery, all births reported thus far have been from orthotopic transplants; spontaneous pregnancies are difficult to predict, and in vitro fertilization is required $[14,46]$. Reports of spontaneous pregnancies and live births following heterotopic transplantations have caused controversy regarding stem cell migration between tissues. Further basic and clinical studies are required to elucidate these mechanisms [112]. Heterotopic transplantation is considered a rarely applied method, as multiple physical and biological requirements related to OT are not met via this approach. In animal studies, offspring are reportedly obtained from heterotopic transplants placed close to the cutaneous area $[113,114]$. Additionally, oocytes and embryos have been obtained in humans as a result of subcutaneous transplantation [115]. Although it may be controversial to classify transplants placed intraabdominally into the peritoneal wall as heterotopic, pregnancy and live births have been obtained using assisted reproduction in this region [116]. Heterotopic transplantation may be suggested if the pelvic region is deemed unsuitable for transplantation due to scars following radiotherapy. 


\section{Current and Future Perspectives on Fertility Preservation}

\section{Whole Ovarian Transplantation}

Whole-ovarian transplantation enables immediate revascularization with blood vessel anastomosis, significantly reducing the risk of ischemic injury [117]. Furthermore, whole cryopreserved ovary transplantation may reduce the risk of ischemic damage; however, cryopreserving a large quantity of intact ovary is challenging due to difficulties in dispersing a sufficient amount of cryoprotective agent throughout the large tissue mass, and the potential injury caused by ice formation in the blood vessels [118]. Considering that human ovarian arteries and veins have a diameter of approximately 0.5 and $3 \mathrm{~mm}$, respectively, vascular anastomosis, a key technical issue, must be considered [119]. Whole ovary cryopreservation and transplantation have been successfully achieved in several experimental animal studies [120,121]. One group concluded that vitrification appeared to be more effective than conventional freezing for whole-ovary cryopreservation. However, another study reported that conventional slow freezing of ovarian cortical strips was more suitable than any other method of whole ovary cryopreservation [122]. Although obstacles and technical difficulties remain [123], human whole ovary cryopreservation and transplantation are encouraged, with future studies likely to solve a majority of current issues [124].

\section{IVM}

IVM has been extensively applied to oocytes obtained from women with polycystic ovarian syndrome [125]. This method involves immature oocyte retrieval from ovaries and either cryopreservation at an immature stage or at a post-IVM matured stage [126]. Both OTC and IVM can be applied to patients with cancer without delaying cancer treatment, including for prepubertal girls and those who need immediate chemotherapy. Moreover, in cancer patients who lack sufficient time for an IVF cycle prior to chemotherapy or radiation therapy, immature oocyte collection may be a promising alternative. Although many researchers aim to achieve improved outcomes by combining IVM of oocytes and vitrification, no live births have been reported from an IVM program in patients with cancer $[125,127]$. A key concern, namely, the auto-transplantation of malignant cells in women who have recovered from cancer, may be eliminated by isolating ovarian follicles from OT and maturing them in vitro [122]. Although oocyte cryopreservation with IVM is still considered an experimental technique [125] that requires further technical improvements, it could potentially be used for fertility preservation in the near future.

\section{Artificial Ovaries}

Studies examining the use of artificial ovaries, or scaffolds, in ovarian transplantation are increasing. The aim of transplanting OT with a scaffold may be to accelerate tissue vascularization through the release of various bioactive substances $[128,129]$ or to optimize tissue transplantation by attaching it to the scaffold using laparoscopic or robotic surgery [130]. Today, it is most commonly used to enable the transplantation of various substances or accessory cells, such as stem cells, together with OT [131-135]. In addition, the technique may be used to develop follicles under in vitro conditions, thereby avoiding tumor contamination or placing these isolated follicles in the transplantation area with the assistance of scaffolds. An artificial ovary can be used to mature oocytes through a multistep process, including sequential in vitro culturing of oocytes, isolated follicles, and OT [136-145]. Multiple studies have shown that the live birth rate using this option is comparable to that of conventional IVF $[146,147]$. Moreover, ovarian follicles cultured in vitro can be reimplanted within a 3D bio-degradable microenvironment. To date, animal studies have demonstrated that this approach restores endocrine function, also enabling in vivo follicular development and successful pregnancy; however, no successful human trials have been reported [138-140, 142]. Developing techniques through which to increase follicular recovery rate and optimize scaffold design, as well as transplantation techniques to prevent postoperative ischemia, and genetic safety considerations, are all necessary for safer and more consistent human clinical applications [136].

\section{Stem Cells}

Recent stem cell studies have investigated the use of ovarian stem cells in fertility preservation. Tilly et al. reported the successful detection and isolation of ovarian stem cells in animals and humans [137, 141]. Furthermore, studies investigating egg-producing stem cells isolated from women's ovaries have observed that these cells differentiate into young oocytes [137]. Oocytes differentiated from ovarian stem cells (OSCs) retrieved from mice were suitable for fertilization and implantation, as evidenced by embryo development and live births [143]. This discovery suggests that therapeutic manipulation of adult stem cells can potentially overcome infertility and prevent ovarian failure. Stem cells may be an option for pre-pubertal girls and women with diverse cancer-associated infertility conditions. However, due to the insufficient clinical application of OCSs in human-assisted reproduction, difficulty in detecting OCSs due to their scarcity, and ethical issues associated with using oocytes and embryos, this technique is not commonly used in clinical practice, especially in cancer patients [148-150]. 
A recent study investigated the effects of adipose-derived stem cells (ASCs) on OTT using an animal model [151]. High ASC concentrations have been shown to increase the human vessel area over time. The ability of ASCs to stimulate human angiogenesis through differentiation and growth factor secretion appears to depend on both cell concentration and time. ASCs grown using a fibrin scaffold served as a substrate to prepare the grafting site over 14 days, also enhancing vascularization following transplantation of human OT. Promoting revascularization by combining OT with angiogenic factors or pro-endothelial stem cells is another approach [152-154]. Further studies are required to implement these approaches in human practice.

\section{Substances for Revascularization}

A key factor affecting the duration of ovarian graft function is the number of surviving oocytes following freeze-thawing and revascularization. Ischemia is a major cause of follicular loss following transplantation, with reoxygenation taking approximately $4-5$ days $[155,156]$. Tissues predominantly depend on anaerobic metabolism early in the posttransplantation period; the shift to aerobic metabolism occurs when oxygenation is provided by neo-vascularization. This is evidenced by the microdialysis experiments performed by Cacciottola et al., in which ischemia was not the only factor in damage, with oxygenation following neo-vascularization potentially triggering the formation of reactive oxygen radicals and contributing to tissue injury during the late stage of graft take [157]. Following the transplantation of frozen/ thawed OT into SCID mice, approximately $28 \%$ of primordial follicles survived the procedure; the remaining follicles died due to ischemic damage [62]. Another study demonstrated that the transplantation site could be treated with vascular endothelial growth factor (VEGF) [158] and stromal cells enriched in CD34 cells to improve angiogenesis [159]. Combined VEGF and bFGF administration induced angiogenesis, reduced apoptosis and fibrosis, and increased the survival of transplanted human OT in a rabbit model [160]. VEGF coupled with FGF2 promoted revascularization and significantly increased the survival rate of transplanted cryopreserved OT, compared with untreated controls, in a mouse model [161]. Treatment with melatonin, or OT incubation with hyaluronan-rich biological glue, in addition to VEGF-A and vitamin E may improve graft survival [162]. In another study, Zhang et al. supplemented the freezing medium with $\mathrm{FSH}$, resulting in increased revascularization and survival of ovarian grafts following vitrification in mice [163].
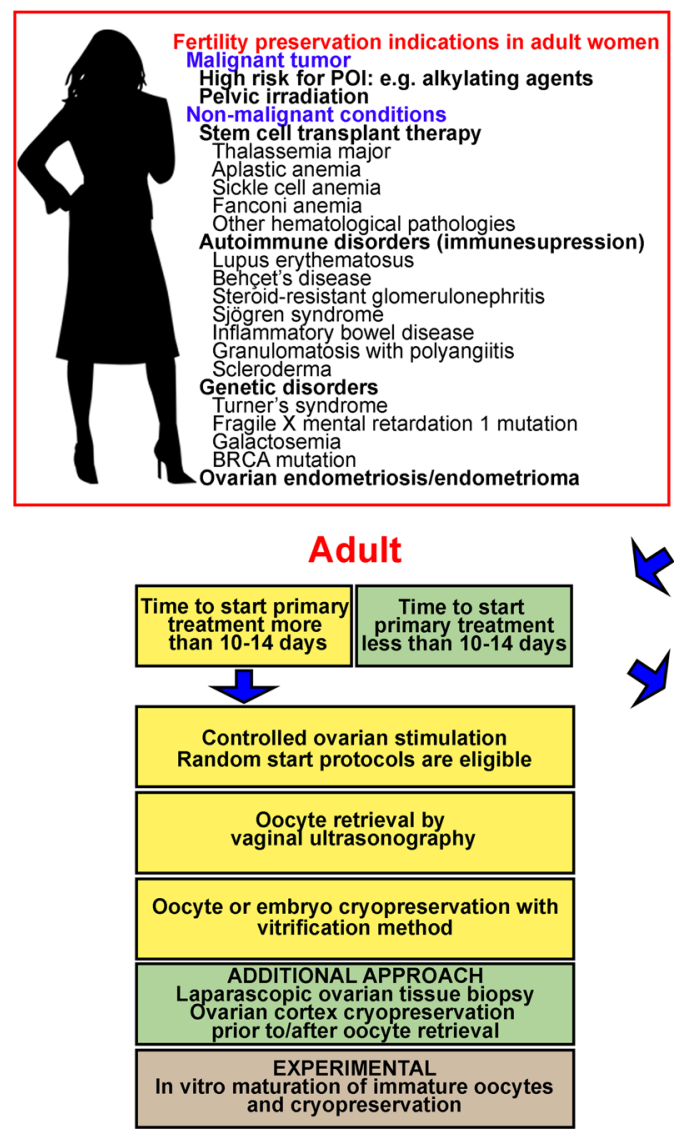

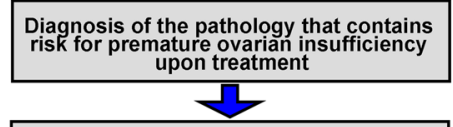

Fertility preservation counseling with patient and her parents if needed
(in case of pre-pubertal girls)

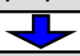

Patient and/or family interested in fertility preservation

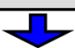

Consultation with patient and/or family Consultation with patient and/or family
Decision of fertility preservation method

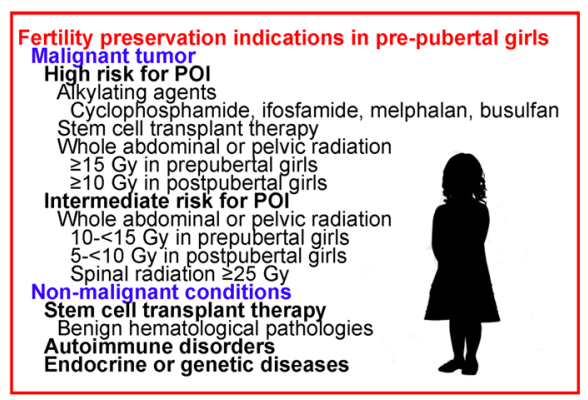

Fertility preservation indications in pre-pubertal girls alignant tumor

Alkylating agents tem cell transplant therapy

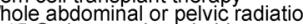
(a) ermediate risk for $\mathrm{PO}$ $5-<10$ Gy in postpubertal girls Spinal radiation $\geq 25$ Gy Stem cell transplant therapy Autoimmune disorders

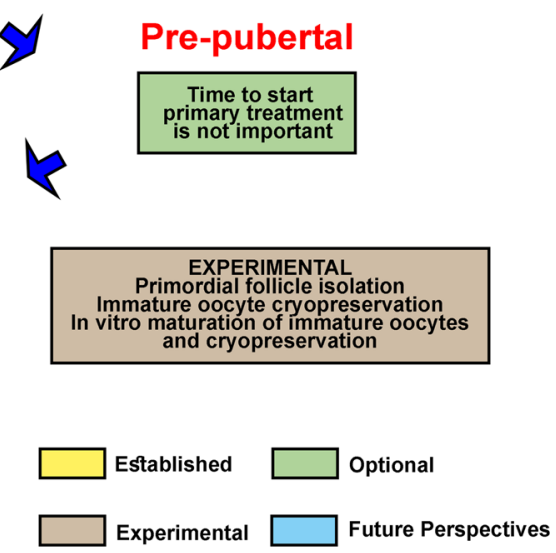

Fig. 1 Current and future perspectives for improving the outcome of fertility preservation in women 


\section{Conclusions}

Advancements in the diagnosis and treatment of cancer have increased the number, and improved the prognosis, of cancer survivors. Although embryo or oocyte cryopreservation is the standard method for fertility preservation, OTC has been declared an acceptable alternative $[18,19]$. Embryo or oocyte cryopreservation for fertility preservation may not be appropriate in women with cancer due to complicated individual conditions and treatment schedules. OTC-T is a promising option for fertility preservation in both pre-pubertal girls and adult patients with cancer who require immediate treatment. The recovery of endocrine function following re-implantation is well established, and the live birth rate has been steadily increasing. To prevent fertility loss in women with cancer, individualized fertility preservation options must be considered, including the patient's age, marital status, chemotherapy regimen, and possibility of treatment delay. Effective multidisciplinary oncofertility strategies (Fig. 1), involving the inclusion of a highly skilled and experienced team, freezingthawing methods, surgical procedures for transplantation, and the latest scientific studies, should be carefully considered for each patient to provide the highest quality of care.

Acknowledgements The authors express deep appreciation for the critical review and kind suggestions of Prof. Stephen B. Howell at the Moores Cancer Center, University of California, San Diego, CA, USA.

This work was supported by a grant from the National Research Foundation of Korea funded by the Korean government (NRF2016R1C1B3015250).

\section{Declarations}

Conflicts of Interest On behalf of all authors, the corresponding author states that there are no conflicts of interest.

Open Access This article is licensed under a Creative Commons Attribution 4.0 International License, which permits use, sharing, adaptation, distribution and reproduction in any medium or format, as long as you give appropriate credit to the original author(s) and the source, provide a link to the Creative Commons licence, and indicate if changes were made. The images or other third party material in this article are included in the article's Creative Commons licence, unless indicated otherwise in a credit line to the material. If material is not included in the article's Creative Commons licence and your intended use is not permitted by statutory regulation or exceeds the permitted use, you will need to obtain permission directly from the copyright holder. To view a copy of this licence, visit http://creativecommons.org/licenses/by/4.0/.

\section{References}

1. Tiong V, Rozita AM, Taib NA, Yip CH, Ng CH. Incidence of chemotherapy-induced ovarian failure in premenopausal women undergoing chemotherapy for breast cancer. World J Surg. 2014;38:2288-96. https://doi.org/10.1007/s00268-014-2542-y.
2. Bray F, Ferlay J, Soerjomataram I, Siegel RL, Torre LA, Jemal A. Global cancer statistics 2018: GLOBOCAN estimates of incidence and mortality worldwide for 36 cancers in 185 countries. CA Cancer J Clin. 2018;68:394-424. https://doi.org/10.3322/ caac. 21492.

3. Jemal A, Siegel R, Ward E, Hao Y, Xu J, Thun MJ. Cancer statistics, 2009. CA Cancer J Clin. 2009;59:225-49. https://doi. org/10.3322/caac.20006.

4. Society AC. Cancer facts \& figures. 2020:2020 https://www. cancer.org/content/dam/cancer-org/research/cancer-facts-andstatistics/annual-cancer-facts-and-figures/2020/special-sectioncancer-in-adolescents-and-young-adults-2020.pdf.

5. Critchley HO, Wallace WH. Impact of cancer treatment on uterine function. J Natl Cancer Inst Monogr. 2005;2005:64-8. https://doi. org/10.1093/jncimonographs/lgi022.

6. Howell S, Shalet S. Gonadal damage from chemotherapy and radiotherapy. Endocrinol Metab Clin N Am. 1998;27:927-43. https://doi.org/10.1016/s0889-8529(05)70048-7.

7. Rodriguez-Wallberg KA, Oktay K. Options on fertility preservation in female cancer patients. Cancer Treat Rev. 2012;38:354-61. https://doi.org/10.1016/j.ctrv.2011.10.002.

8. Carrillo L, Seidman DS, Cittadini E, Meirow D. The role of fertility preservation in patients with endometriosis. J Assist Reprod Genet. 2016;33:317-23. https://doi.org/10.1007/s10815-0160646-z.

9. Somigliana E, Vigano P, Filippi F, Papaleo E, Benaglia L, Candiani M, et al. Fertility preservation in women with endometriosis: for all, for some, for none? Hum Reprod. 2015;30:1280-6. https://doi.org/10.1093/humrep/dev078.

10. Donnez J, Dolmans MM. Fertility preservation in women. N Engl J Med. 2017;377:1657-65.https://doi.org/10.1056/ NEJMra1614676.

11. Kim H, Kim H, Ku SY. Fertility preservation in pediatric and young adult female cancer patients. Ann Pediatr Endocrinol Metab. 2018;23:70-4. https://doi.org/10.6065/apem.2018.23.2. 70.

12. Lee S, Ozkavukcu S, Heytens E, Moy F, Oktay K. Value of early referral to fertility preservation in young women with breast cancer. J Clin Oncol. 2010;28:4683-6. https://doi.org/10.1200/JCO. 2010.30.5748.

13. Richards L. Fertility: the importance of early referral to fertility preservation. Nat Rev Clin Oncol. 2011;8:4. https://doi.org/10. 1038/nrclinonc.2010.200.

14. Kim S, Lee Y, Lee S, Kim T. Ovarian tissue cryopreservation and transplantation in patients with cancer. Obstet Gynecol Sci. 2018;61:431-42. https://doi.org/10.5468/ogs.2018.61.4.431.

15. Gellert SE, Pors SE, Kristensen SG, Bay-Bjorn AM, Ernst E, Yding AC. Transplantation of frozen-thawed ovarian tissue: an update on worldwide activity published in peer-reviewed papers and on the Danish cohort. J Assist Reprod Genet. 2018;35:56170. https://doi.org/10.1007/s10815-018-1144-2.

16. Vajta G, Nagy ZP. Are programmable freezers still needed in the embryo laboratory? Review on vitrification Reprod Biomed Online. 2006;12:779-96. https://doi.org/10.1016/s1472-6483(10) 61091-7.

17. Jensen AK, Macklon KT, Fedder J, Ernst E, Humaidan P, Andersen CY. 86 successful births and 9 ongoing pregnancies worldwide in women transplanted with frozen-thawed ovarian tissue: focus on birth and perinatal outcome in 40 of these children. J Assist Reprod Genet. 2017;34:325-36. https://doi.org/10. 1007/s10815-016-0843-9.

18. Practice Committee of the American Society for Reproductive Medicine. Electronic address aao. Fertility preservation in patients undergoing gonadotoxic therapy or gonadectomy: a committee opinion. Fertil Steril. 2019; https://doi.org/10.1016/j.fertnstert. 2019.09.013 
19. Preservation TEGGoFF, Anderson RA, Amant F, Braat D, D'Angelo A, Chuva de Sousa Lopes SM, et al. ESHRE guideline: female fertility preservation†. Hum Reprod Open. 2020; https:// doi.org/10.1093/hropen/hoaa052.

20. Dolmans MM, Marinescu C, Saussoy P, Van Langendonckt A, Amorim C, Donnez J. Reimplantation of cryopreserved ovarian tissue from patients with acute lymphoblastic leukemia is potentially unsafe. Blood. 2010;116:2908-14. https://doi.org/10.1182/ blood-2010-01-265751.

21. Greve T, Clasen-Linde E, Andersen MT, Andersen MK, Sorensen $\mathrm{SD}$, Rosendahl M, et al. Cryopreserved ovarian cortex from patients with leukemia in complete remission contains no apparent viable malignant cells. Blood. 2012;120:4311-6. https://doi.org/ 10.1182/blood-2012-01-403022.

22. Han HS, Ro J, Lee KS, Nam BH, Seo JA, Lee DH, et al. Analysis of chemotherapy-induced amenorrhea rates by three different anthracycline and taxane containing regimens for early breast cancer. Breast Cancer Res Treat. 2009;115:335-42. https://doi.org/ 10.1007/s10549-008-0071-9.

23. Meirow D. Reproduction post-chemotherapy in young cancer patients. Mol Cell Endocrinol. 2000;169:123-31. https://doi.org/10. 1016/s0303-7207(00)00365-8.

24. Meirow D, Nugent D. The effects of radiotherapy and chemotherapy on female reproduction. Hum Reprod Update. 2001;7:53543. https://doi.org/10.1093/humupd/7.6.535.

25. Wallace WHB, Anderson RA, Irvine DS. Fertility preservation for young patients with cancer: who is at risk and what can be offered? Lancet Oncol. 2005;6:209-18. https://doi.org/10.1016/s14702045(05)70092-9.

26. Luan Y, Edmonds ME, Woodruff TK, Kim SY. Inhibitors of apoptosis protect the ovarian reserve from cyclophosphamide. J Endocrinol. 2019;240:243-56. https://doi.org/10.1530/JOE-180370.

27. Petrillo SK, Desmeules P, Truong TQ, Devine PJ. Detection of DNA damage in oocytes of small ovarian follicles following phosphoramide mustard exposures of cultured rodent ovaries in vitro. Toxicol Appl Pharmacol. 2011;253:94-102. https://doi. org/10.1016/j.taap.2011.03.012.

28. Soleimani R, Heytens E, Darzynkiewicz Z, Oktay K. Mechanisms of chemotherapy-induced human ovarian aging: double strand DNA breaks and microvascular compromise. Aging (Albany NY). 2011; https://doi.org/10.18632/aging.100363.

29. Szymanska KJ, Tan X, Oktay K. Unraveling the mechanisms of chemotherapy-induced damage to human primordial follicle reserve: road to developing therapeutics for fertility preservation and reversing ovarian aging. Mol Hum Reprod. 2020;26:55366. https://doi.org/10.1093/molehr/gaaa043.

30. Meirow D, Dor J, Kaufman B, Shrim A, Rabinovici J, Schiff E, et al. Cortical fibrosis and blood-vessels damage in human ovaries exposed to chemotherapy. Potential mechanisms of ovarian injury. Hum Reprod. 2007; doi:https://doi.org/10.1093/humrep/ dem027

31. Chang EM, Lim E, Yoon S, Jeong K, Bae S, Lee DR, et al. Cisplatin induces overactivation of the dormant primordial follicle through PTEN/AKT/FOXO3a pathway which leads to loss of ovarian reserve in mice. PLoS One. 2015;10:e0144245. https:// doi.org/10.1371/journal.pone.0144245.

32. Kalich-Philosoph L, Roness H, Carmely A, Fishel-Bartal M, Ligumsky H, Paglin S, et al. Cyclophosphamide triggers follicle activation and "burnout"; AS101 prevents follicle loss and preserves fertility. Sci Transl Med. 2013;5:185ra62. https://doi.org/ 10.1126/scitranslmed.3005402.

33. Ayuandari S, Winkler-Crepaz K, Paulitsch M, Wagner C, Zavadil C, Manzl C, et al. Follicular growth after xenotransplantation of cryopreserved/thawed human ovarian tissue in SCID mice: dynamics and molecular aspects. J Assist Reprod Genet. 2016;33:1585-93. https://doi.org/10.1007/s10815-016-0769-2.

34. Wo JY, Viswanathan AN. Impact of radiotherapy on fertility, pregnancy, and neonatal outcomes in female cancer patients. Int J Radiat Oncol Biol Phys. 2009;73:1304-12. https://doi.org/10. 1016/j.ijrobp.2008.12.016.

35. Green DM, Sklar CA, Boice JD Jr, Mulvihill JJ, Whitton JA, Stovall M, et al. Ovarian failure and reproductive outcomes after childhood cancer treatment: results from the Childhood Cancer Survivor Study. J Clin Oncol. 2009;27:2374-81. https://doi.org/ 10.1200/JCO.2008.21.1839.

36. Wallace WH, Thomson AB, Saran F, Kelsey TW. Predicting age of ovarian failure after radiation to a field that includes the ovaries. Int J Radiat Oncol Biol Phys. 2005;62:738-44. https://doi.org/10. 1016/j.ijrobp.2004.11.038.

37. Karraker A, Latham K. In sickness and in health? Physical illness as a risk factor for marital dissolution in later life. J Health Soc Behav. 2015;56:420-35. https://doi.org/10.1177/ 0022146515596354.

38. Lee S, Ryu KJ, Kim B, Kang D, Kim YY, Kim T. Comparison between slow freezing and vitrification for human ovarian tissue cryopreservation and xenotransplantation. Int J Mol Sci. 2019;20. https://doi.org/10.3390/ijms20133346.

39. Shi Q, Xie Y, Wang Y, Li S. Vitrification versus slow freezing for human ovarian tissue cryopreservation: a systematic review and meta-anlaysis. Sci Rep. 2017;7:8538. https://doi.org/10.1038/ s41598-017-09005-7.

40. Gandolfi F, Paffoni A, Papasso Brambilla E, Bonetti S, Brevini TA, Ragni G. Efficiency of equilibrium cooling and vitrification procedures for the cryopreservation of ovarian tissue: comparative analysis between human and animal models. Fertil Steril. 2006;85: 1150-6. https://doi.org/10.1016/j.fertnstert.2005.08.062.

41. Oktem O, Alper E, Balaban B, Palaoglu E, Peker K, Karakaya C, et al. Vitrified human ovaries have fewer primordial follicles and produce less antimullerian hormone than slow-frozen ovaries. Fertil Steril. 2011;95:2661-2664.e1. https://doi.org/10.1016/j. fertnstert.2010.12.057.

42. Kawamura K, Cheng Y, Suzuki N, Deguchi M, Sato Y, Takae S, et al. Hippo signaling disruption and Akt stimulation of ovarian follicles for infertility treatment. Proc Natl Acad Sci U S A. 2013;110:17474-9. https://doi.org/10.1073/pnas.1312830110.

43. Silber S. How ovarian transplantation works and how resting follicle recruitment occurs: a review of results reported from one center. Womens Health (Lond). 2016;12:217-27. https://doi.org/ 10.2217/whe.15.108.

44. Sugishita Y, Okamoto N, Uekawa A, Yamochi T, Nakajima M, Namba C, et al. Oocyte retrieval after heterotopic transplantation of ovarian tissue cryopreserved by closed vitrification protocol. J Assist Reprod Genet. 2018;35:2037-48. https://doi.org/10.1007/ s10815-018-1298-y.

45. Leonel ECR, Corral A, Risco R, Camboni A, Taboga SR, Kilbride $\mathrm{P}$, et al. Stepped vitrification technique for human ovarian tissue cryopreservation. Sci Rep. 2019;9:20008. https://doi.org/10.1038/ s41598-019-56585-7.

46. Donnez J, Dolmans MM, Pellicer A, Diaz-Garcia C, Sanchez Serrano M, Schmidt KT, et al. Restoration of ovarian activity and pregnancy after transplantation of cryopreserved ovarian tissue: a review of 60 cases of reimplantation. Fertil Steril. 2013;99: 1503-13. https://doi.org/10.1016/j.fertnstert.2013.03.030.

47. Donnez J, Dolmans MM, Pellicer A, Diaz-Garcia C, Ernst E, Macklon KT, et al. Fertility preservation for age-related fertility decline. Lancet. 2015;385:506-7. https://doi.org/10.1016/S01406736(15)60198-2.

48. Khan HL, Bhatti S, Suhail S, Gul R, Awais A, Hamayun H, et al. Antral follicle count (AFC) and serum anti-Müllerian hormone $(\mathrm{AMH})$ are the predictors of natural fecundability have similar 
trends irrespective of fertility status and menstrual characteristics among fertile and infertile women below the age of 40 years. Reprod Biol Endocrinol. 2019;17:20. https://doi.org/10.1186/ s12958-019-0464-0.

49. Backhus LE, Kondapalli LA, Chang RJ, Coutifaris C, Kazer R, Woodruff TK. Oncofertility consortium consensus statement: guidelines for ovarian tissue cryopreservation. Cancer Treat Res. 2007. https://doi.org/10.1007/978-0-387-72293-1_17.

50. Gosden RG. Low temperature storage and grafting of human ovarian tissue. Mol Cell Endocrinol. 2000;163:125-9. https://doi.org/ 10.1016/s0303-7207(99)00248-8.

51. Gook DA. Human ovarian tissue slow freezing. In: Methods in Molecular Biology. New York: Springer; 2017. pp. 161-176.

52. Jadoul P, Guilmain A, Squifflet J, Luyckx M, Votino R, Wyns C, et al. Efficacy of ovarian tissue cryopreservation for fertility preservation: lessons learned from 545 cases. Hum Reprod. 2017;32: 1046-54. https://doi.org/10.1093/humrep/dex040.

53. Schmidt KT, Rosendahl M, Ernst E, Loft A, Andersen AN, Dueholm M, et al. Autotransplantation of cryopreserved ovarian tissue in 12 women with chemotherapy-induced premature ovarian failure: the Danish experience. Fertil Steril. 2011;95:695-701. https://doi.org/10.1016/j.fertnstert.2010.07.1080.

54. Amorim CA, Dolmans MM, David A, Jaeger J, Vanacker J, Camboni A, et al. Vitrification and xenografting of human ovarian tissue. Fertil Steril. 2012;98:1291-1298.e2. https://doi.org/10. 1016/j.fertnstert.2012.07.1109.

55. Yding Andersen C, Mamsen LS, Kristensen SG. FERTILITY PRESERVATION: freezing of ovarian tissue and clinical opportunities. Reproduction. 2019;158:F27-34. https://doi.org/10. 1530/REP-18-0635.

56. Brayton CF. Dimethyl sulfoxide (DMSO): a review. Cornell Vet. 1986;76(1):61-90.

57. Kang MH, Das J, Gurunathan S, Park HW, Song H, Park C, et al. The cytotoxic effects of dimethyl sulfoxide in mouse preimplantation embryos: a mechanistic study. Theranostics. 2017;7:473552. https://doi.org/10.7150/thno.21662.

58. Aye M, Di Giorgio C, De Mo M, Botta A, Perrin J, Courbiere B. Assessment of the genotoxicity of three cryoprotectants used for human oocyte vitrification: dimethyl sulfoxide, ethylene glycol and propylene glycol. Food Chem Toxicol. 2010;48:1905-12. https://doi.org/10.1016/j.fct.2010.04.032.

59. Kasai M, Mukaida T. Cryopreservation of animal and human embryos by vitrification. Reprod BioMed Online. 2004;9:164 70. https://doi.org/10.1016/s1472-6483(10)62125-6.

60. Martino NA, Dell'aquila ME, Cardone RA, Somoskoi B, Lacalandra GM, Cseh S. Vitrification preserves chromatin integrity, bioenergy potential and oxidative parameters in mouse embryos. Reprod Biol Endocrinol. 2013;11:27. https://doi.org/10. 1186/1477-7827-11-27.

61. Coello A, Campos P, Remohí J, Meseguer M, Cobo A. A combination of hydroxypropyl cellulose and trehalose as supplementation for vitrification of human oocytes: a retrospective cohort study. J Assist Reprod Genet. 2016;33:413-21. https://doi.org/ 10.1007/s10815-015-0633-9.

62. Baird DT, Webb R, Campbell BK, Harkness LM, Gosden RG. Long-term ovarian function in sheep after ovariectomy and transplantation of autografts stored at -196 C. Endocrinology. 1999;140:462-71. https://doi.org/10.1210/endo.140.1.6453.

63. Liu J, Van der Elst J, Van den Broecke R, Dhont M. Early massive follicle loss and apoptosis in heterotopically grafted newborn mouse ovaries. Hum Reprod. 2002;17:605-11. https://doi.org/ 10.1093/humrep/17.3.605.

64. Yang H, Lee HH, Lee HC, Ko DS, Kim SS. Assessment of vascular endothelial growth factor expression and apoptosis in the ovarian graft: can exogenous gonadotropin promote angiogenesis after ovarian transplantation? Fertil Steril. 2008;90:1550-8. https://doi.org/10.1016/j.fertnstert.2007.08.086.

65. Hannoun A, Ghaziri G, Abu Musa A, Zreik TG, Hajameh F, Awwad J. Addition of sphingosine-1-phosphate to human oocyte culture medium decreases embryo fragmentation. Reprod BioMed Online. 2010;20:328-34. https://doi.org/10.1016/j.rbmo.2009.11. 020.

66. Morita Y, Perez GI, Paris F, Miranda SR, Ehleiter D, HaimovitzFriedman A, et al. Oocyte apoptosis is suppressed by disruption of the acid sphingomyelinase gene or by sphingosine-1-phosphate therapy. Nat Med. 2000;6:1109-14. https://doi.org/10.1038/ 80442 .

67. Geng X, Guo L, Zeng W, Ma L, Ou X, Luo C, et al. Effects of sphingosine-1-phosphate on gene expression of two cell mouse embryos induced by C2-Ceramide. Middle East Fertil Soc J. 2014;19:107-14. https://doi.org/10.1016/j.mefs.2013.06.001.

68. Soleimani R, Heytens E, Oktay K. Enhancement of neoangiogenesis and follicle survival by sphingosine-1phosphate in human ovarian tissue xenotransplants. PLoS One. 2011;6:e19475. https://doi.org/10.1371/journal.pone.0019475.

69. Tsai YC, Tzeng CR, Wang CW, Hsu MI, Tan SJ, Chen CH. Antiapoptotic agent sphingosine-1-phosphate protects vitrified murine ovarian grafts. Reprod Sci. 2014;21:236-43. https://doi. org/10.1177/1933719113493515.

70. Fransolet M, Noël L, Henry L, Labied S, Blacher S, Nisolle M, et al. Evaluation of Z-VAD-FMK as an anti-apoptotic drug to prevent granulosa cell apoptosis and follicular death after human ovarian tissue transplantation. J Assist Reprod Genet. 2019;36: 349-59. https://doi.org/10.1007/s10815-018-1353-8.

71. Lee S, Ozkavukcu S, Heytens E, Moy F, Alappat RM, Oktay K. Anti-Mullerian hormone and antral follicle count as predictors for embryo/oocyte cryopreservation cycle outcomes in breast cancer patients stimulated with letrozole and follicle stimulating hormone. J Assist Reprod Genet. 2011;28:651-6. https://doi.org/10. 1007/s10815-011-9567-z.

72. Sonigo C, Beau I, Binart N, Grynberg M. Anti-Müllerian hormone in fertility preservation: clinical and therapeutic applications. Clin Med Insights Reprod Health. 2019;13:117955811985475. https:// doi.org/10.1177/1179558119854755.

73. Carlsson IB, Scott JE, Visser JA, Ritvos O, Themmen AP, Hovatta O. Anti-Müllerian hormone inhibits initiation of growth of human primordial ovarian follicles in vitro. Hum Reprod. 2006;21:2223-7. https://doi.org/10.1093/humrep/del165.

74. Kushnir VA, Halevy N, Barad DH, Albertini DF, Gleicher N. Relative importance of $\mathrm{AMH}$ and androgens changes with aging among non-obese women with polycystic ovary syndrome. J Ovarian Res. 2015;8:45. https://doi.org/10.1186/s13048-0150175-x.

75. Kano M, Sosulski AE, Zhang L, Saatcioglu HD, Wang D, Nagykery N, et al. AMH/MIS as a contraceptive that protects the ovarian reserve during chemotherapy. Proc Natl Acad Sci U S A. 2017;114:E1688-97. https://doi.org/10.1073/pnas. 1620729114.

76. Man L, Park L, Bodine R, Ginsberg M, Zaninovic N, Man OA, et al. Engineered endothelium provides angiogenic and paracrine stimulus to grafted human ovarian tissue. Sci Rep. 2017;7:8203. https://doi.org/10.1038/s41598-017-08491-z.

77. Pepin D, Sabatini ME, Donahoe PK. Müllerian inhibiting substance/anti-Müllerian hormone as a fertility preservation agent. Curr Opin Endocrinol Diabetes Obes. 2018;25:399-405. https:// doi.org/10.1097/MED.0000000000000442.

78. Kushnir VA, Seifer DB, Barad DH, Sen A, Gleicher N. Potential therapeutic applications of human anti-Müllerian hormone $(\mathrm{AMH})$ analogues in reproductive medicine. J Assist Reprod Genet. 2017;34:1105-13. https://doi.org/10.1007/s10815-0170977-4. 
79. Yoon TK, Lee DR, Cha SK, Chung HM, Lee WS, Cha KY. Survival rate of human oocytes and pregnancy outcome after vitrification using slush nitrogen in assisted reproductive technologies. Fertil Steril. 2007;88:952-6. https://doi.org/10.1016/j. fertnstert.2006.12.071.

80. Criado E, Albani E, Novara PV, Smeraldi A, Cesana A, Parini V, et al. Human oocyte ultravitrification with a low concentration of cryoprotectants by ultrafast cooling: a new protocol. Fertil Steril. 2011;95:1101-3. https://doi.org/10.1016/j.fertnstert.2010.11.015.

81. Minasi MG, Fabozzi G, Casciani V, Ferrero S, Litwicka K, Greco E. Efficiency of slush nitrogen vitrification of human oocytes vitrified with or without cumulus cells in relation to survival rate and meiotic spindle competence. Fertil Steril. 2012;97:1220-5. https:// doi.org/10.1016/j.fertnstert.2012.02.022.

82. Santos MV, Sansinena M, Zaritzky N, Chirife J. Assessment of external heat transfer coefficient during oocyte vitrification in liquid and slush nitrogen using numerical simulations to determine cooling rates. Cryo-Letters. 2012;33(1):31-40.

83. Talevi R, Barbato V, Fiorentino I, Braun S, De Stefano C, Ferraro $\mathrm{R}$, et al. Successful slush nitrogen vitrification of human ovarian tissue. Fertil Steril. 2016;105:1523-1531.e1. https://doi.org/10. 1016/j.fertnstert.2016.01.043.

84. Jin B, Mazur P. High survival of mouse oocytes/embryos after vitrification without permeating cryoprotectants followed by ultra-rapid warming with an IR laser pulse. Sci Rep. 2015;5. https://doi.org/10.1038/srep09271.

85. Darwish E, Magdi Y. Artificial shrinkage of blastocoel using a laser pulse prior to vitrification improves clinical outcome. J Assist Reprod Genet. 2016;33:467-71. https://doi.org/10.1007/s10815016-0662-z.

86. Loren AW, Senapati S. Fertility preservation in patients with hematologic malignancies and recipients of hematopoietic cell transplants. Blood. 2019;134:746-60. https://doi.org/10.1182/blood. 2018846790

87. Salama M, Anazodo A, Woodruff TK. Preserving fertility in female patients with hematological malignancies: the key points. Expert Rev Hematol. 2019;12:375-7. https://doi.org/10.1080/ 17474086.2019.1613150.

88. Dolmans MM, Luyckx V, Donnez J, Andersen CY, Greve T. Risk of transferring malignant cells with transplanted frozen-thawed ovarian tissue. Fertil Steril. 2013;99:1514-22. https://doi.org/10. 1016/j.fertnstert.2013.03.027.

89. Rosendahl M, Andersen MT, Ralfkiaer E, Kjeldsen L, Andersen MK, Andersen CY. Evidence of residual disease in cryopreserved ovarian cortex from female patients with leukemia. Fertil Steril. 2010;94(6):2186-90. https://doi.org/10.1016/j.fertnstert.2009.11. 032 .

90. Shapira M, Raanani H, Barshack I, Amariglio N, Derech-Haim S, Marciano MN, et al. First delivery in a leukemia survivor after transplantation of cryopreserved ovarian tissue, evaluated for leukemia cells contamination. Fertil Steril. 2018;109:48-53. https:// doi.org/10.1016/j.fertnstert.2017.09.001.

91. Sonmezer M, Ozkavukcu S, Sukur YE, Kankaya D, Arslan O. First pregnancy and live birth in Turkey following frozenthawed ovarian tissue transplantation in a patient with acute lymphoblastic leukemia who underwent cord blood transplantation. $\mathrm{J}$ Assist Reprod Genet. 2020;37:2033-43. https://doi.org/10.1007/ s10815-020-01850-2.

92. Meirow D, Ra'anani H, Shapira M, Brenghausen M, Derech Chaim S, Aviel-Ronen S, et al. Transplantations of frozenthawed ovarian tissue demonstrate high reproductive performance and the need to revise restrictive criteria. Fertil Steril. 2016;106: 467-74. https://doi.org/10.1016/j.fertnstert.2016.04.031.

93. Mulder CL, Eijkenboom LL, Beerendonk CCM, Braat DDM, Peek R. Enhancing the safety of ovarian cortex autotransplantation: cancer cells are purged completely from human ovarian tissue fragments by pharmacological inhibition of YAP/TAZ oncoproteins. Hum Reprod. 2019;34:506-18. https://doi.org/10.1093/humrep/dey384.

94. Meirow D, Hardan I, Dor J, Fridman E, Elizur S, Ra'anani H, et al. Searching for evidence of disease and malignant cell contamination in ovarian tissue stored from hematologic cancer patients. Hum Reprod. 2008;23:1007-13. https://doi.org/10.1093/humrep/ den 055.

95. Rauff S, Giorgione V, Andersen CY. Potential malignant cell contamination in transplanted ovarian tissue. Expert Opin Biol Ther. 2016;16:285-9. https://doi.org/10.1517/14712598.2015. 1134482 .

96. Lee S, Song JY, Ku SY, Kim SH, Kim T. Fertility preservation in women with cancer. Clin Exp Reprod Med. 2012;39:46-51. https://doi.org/10.5653/cerm.2012.39.2.46.

97. Beckmann MW, Dittrich R, Findeklee S, Lotz L. Surgical aspects of ovarian tissue removal and ovarian tissue transplantation for fertility preservation. Geburtshilfe Frauenheilkd. 2016;76:105764. https://doi.org/10.1055/s-0042-115017.

98. Oktay K, Karlikaya G. Ovarian function after transplantation of frozen, banked autologous ovarian tissue. N Engl J Med. $2000 ; 342: 1919$. https://doi.org/10.1056/ NEJM200006223422516.

99. Oktay K, Oktem O. Ovarian cryopreservation and transplantation for fertility preservation for medical indications: report of an ongoing experience. Fertil Steril. 2010;93:762-8. https://doi.org/10. 1016/j.fertnstert.2008.10.006.

100. Donnez J, Dolmans MM, Demylle D, Jadoul P, Pirard C, Squifflet $\mathrm{J}$, et al. Livebirth after orthotopic transplantation of cryopreserved ovarian tissue. Lancet. 2004;364:1405-10. https://doi.org/10. 1016/S0140-6736(04)17222-X.

101. Oktay K, Taylan E, Sugishita Y, Goldberg GM. Robot-assisted laparoscopic transplantation of frozen-thawed ovarian tissue. J Minim Invasive Gynecol. 2017;24:897-8. https://doi.org/10. 1016/j.jmig.2017.02.021.

102. Karavani G, Schachter-Safrai N, Chill HH, Mordechai Daniel T, Bauman D, Revel A. Single-incision laparoscopic surgery for ovarian tissue cryopreservation. J Minim Invasive Gynecol. 2018;25:474-9. https://doi.org/10.1016/j.jmig.2017.10.007.

103. Corkum KS, Laronda MM, Rowell EE. A review of reported surgical techniques in fertility preservation for prepubertal and adolescent females facing a fertility threatening diagnosis or treatment. Am J Surg. 2017;214:695-700. https://doi.org/10.1016/j. amjsurg.2017.06.013.

104. Lawrenz B, Jauckus J, Kupka MS, Strowitzki T, von Wolff M. Fertility preservation in $>1,000$ patients: patient's characteristics, spectrum, efficacy and risks of applied preservation techniques. Arch Gynecol Obstet. 2011;283:651-6. https://doi.org/10.1007/ s00404-010-1772-y.

105. Lee S, Song J, Kim T, Kim S. Ovarian tissue cryopreservation and transplantation in a young patient with cervical cancer: the first successful case in Korea. Eur J Gynaecol Oncol. 2019. https://doi. org/10.12892/ejgo4564.2019.

106. Kiran G, Kiran H, Coban Y, Guven A, Yuksel M. Fresh autologous transplantation of ovarian cortical strips to the anterior abdominal wall at the pfannenstiel incision site. Fertil Steril. 2004;82:954-6. https://doi.org/10.1016/j.fertnstert.2004.06.007.

107. Oktay K, Buyuk E, Rosenwaks Z, Rucinski J. A technique for transplantation of ovarian cortical strips to the forearm. Fertil Steril. 2003;80:193-8. https://doi.org/10.1016/s0015-0282(03) 00568-5.

108. Rosendahl M, Schmidt KT, Ernst E, Rasmussen PE, Loft A, Byskov AG, et al. Cryopreservation of ovarian tissue for a decade in Denmark: a view of the technique. Reprod BioMed Online. 2011;22:162-71. https://doi.org/10.1016/j.rbmo.2010.10.015. 
109. Silber S, Kagawa N, Kuwayama M, Gosden R. Duration of fertility after fresh and frozen ovary transplantation. Fertil Steril. 2010;94:2191-6. https://doi.org/10.1016/j.fertnstert.2009.12.073.

110. Donnez J, Dolmans M-M. Transplantation of ovarian tissue. Best Pract Res Clin Obstet Gynaecol. 2014;28:1188-97. https://doi. org/10.1016/j.bpobgyn.2014.09.003.

111. Donnez J, Jadoul P, Pirard C, Hutchings G, Demylle D, Squifflet $\mathrm{J}$, et al. Live birth after transplantation of frozen-thawed ovarian tissue after bilateral oophorectomy for benign disease. Fertil Steril. 2012;98:720-5. https://doi.org/10.1016/j.fertnstert.2012.05.017.

112. Oktay K. Spontaneous conceptions and live birth after heterotopic ovarian transplantation: is there a germline stem cell connection? Hum Reprod. 2006;21:1345-8. https://doi.org/10.1093/humrep/ del007.

113. Li S, Qin BL, Li WL, Shi ZD, Tian YB, Chen XJ. Offspring from heterotopic transplantation of newborn mice ovaries. Reprod Domest Anim. 2009;44:764-70. https://doi.org/10.1111/j.14390531.2008.01069.x.

114. Waterhouse T, Cox SL, Snow M, Jenkin G, Shaw J. Offspring produced from heterotopic ovarian allografts in male and female recipient mice. Reproduction. 2004;127:689-94. https://doi.org/ 10.1530/rep.1.00081.

115. Oktay K, Buyuk E, Veeck L, Zaninovic N, Xu K, Takeuchi T, et al. Embryo development after heterotopic transplantation of cryopreserved ovarian tissue. Lancet. 2004;363:837-40. https:// doi.org/10.1016/s0140-6736(04)15728-0.

116. Tammiste T, Kask K, Padrik P, Idla K, Rosenstein K, Jatsenko T, et al. A case report and follow-up of the first live birth after heterotopic transplantation of cryopreserved ovarian tissue in Eastern Europe. BMC Womens Health. 2019;19:65. https://doi.org/10. 1186/s12905-019-0764-8.

117. Bedaiwy MA. Ovarian tissue banking for cancer patients: reduction of post-transplantation ischaemic injury: intact ovary freezing and transplantation. Hum Reprod. 2004;19:1242-4. https://doi. org/10.1093/humrep/deh262.

118. Martinez-Madrid B, Dolmans M-M, Van Langendonckt A, Defrère $S$, Donnez J. Freeze-thawing intact human ovary with its vascular pedicle with a passive cooling device. Fertil Steril. 2004;82:1390-4. https://doi.org/10.1016/j.fertnstert.2004.06.036.

119. Silber SJ, Grudzinskas G, Gosden RG. Successful pregnancy after microsurgical transplantation of an intact ovary. N Engl J Med. 2008;359:2617-8. https://doi.org/10.1056/nejmc0804321.

120. Revel A, Elami A, Bor A, Yavin S, Natan Y, Arav A. Whole sheep ovary cryopreservation and transplantation. Fertil Steril. 2004;82:1714-5. https://doi.org/10.1016/j.fertnstert.2004.06.046.

121. Yin H. Transplantation of intact rat gonads using vascular anastomosis: effects of cryopreservation, ischaemia and genotype. Hum Reprod. 2003;18:1165-72. https://doi.org/10.1093/humrep/ $\operatorname{deg} 236$.

122. Zhang J-M, Sheng Y, Cao Y-Z, Wang H-Y, Chen Z-J. Cryopreservation of whole ovaries with vascular pedicles: vitrification or conventional freezing? J Assist Reprod Genet. 2011;28: 445-52. https://doi.org/10.1007/s10815-011-9539-3.

123. Zhang S, Yao H, Liu Y, Ren L, Xiang D, Wang Y. Hypothermic machine perfusion after static cold storage improves ovarian function in rat ovarian tissue transplantation. J Assist Reprod Genet. 2020;37:1745-53. https://doi.org/10.1007/s10815-020-01797-4.

124. Hossay C, Donnez J, Dolmans MM. Whole ovary cryopreservation and transplantation: a systematic review of challenges and research developments in animal experiments and humans. $\mathrm{J}$ Clin Med. 2020;9. https://doi.org/10.3390/jcm9103196.

125. Son W-Y, Henderson S, Cohen Y, Dahan M, Buckett W. Immature oocyte for fertility preservation. Front Endocrinol. 2019;10. https://doi.org/10.3389/fendo.2019.00464.

126. Lee JA, Barritt J, Moschini RM, Slifkin RE, Copperman AB. Optimizing human oocyte cryopreservation for fertility preservation patients: should we mature then freeze or freeze then mature? Fertil Steril. 2013;99:1356-62. https://doi.org/10.1016/j. fertnstert.2012.11.042.

127. Huang JYJ, Buckett WM, Gilbert L, Tan SL, Chian R-C. Retrieval of immature oocytes followed by in vitro maturation and vitrification: A case report on a new strategy of fertility preservation in women with borderline ovarian malignancy. Gynecol Oncol. 2007;105:542-4. https://doi.org/10.1016/j.ygyno.2007.01.036.

128. Tavana S, Azarnia M, Valojerdi MR, Shahverdi A. Hyaluronic acid-based hydrogel scaffold without angiogenic growth factors enhances ovarian tissue function after autotransplantation in rats. Biomed Mater. 2016;11. https://doi.org/10.1088/1748-6041/11/5/ 055006.

129. Tavana S, Valojerdi MR, Azarnia M, Shahverdi A. Restoration of ovarian tissue function and estrous cycle in rat after autotransplantation using hyaluronic acid hydrogel scaffold containing VEGF and bFGF. Growth Factors. 2016;34:97-106. https://doi.org/10.1080/08977194.2016.1194835.

130. Oktay K, Bedoschi G, Pacheco F, Turan V, Emirdar V. First pregnancies, live birth, and in vitro fertilization outcomes after transplantation of frozen-banked ovarian tissue with a human extracellular matrix scaffold using robot-assisted minimally invasive surgery. Am J Obstet Gynecol. 2016;214:94.e1-9. https://doi.org/ 10.1016/j.ajog.2015.10.001.

131. Dolmans MM, Cacciottola L, Amorim CA, Manavella D. Translational research aiming to improve survival of ovarian tissue transplants using adipose tissue-derived stem cells. Acta Obstet Gynecol Scand. 2019;98:665-71. https://doi.org/10.1111/ aogs.13610.

132. Man L, Park L, Bodine R, Ginsberg M, Zaninovic N, Schattman $\mathrm{G}$, et al. Co-transplantation of human ovarian tissue with engineered endothelial cells: a cell-based strategy combining accelerated perfusion with direct paracrine delivery. J Vis Exp. 2018. https://doi.org/10.3791/57472.

133. Manavella DD, Cacciottola L, Payen VL, Amorim CA, Donnez J, Dolmans MM. Adipose tissue-derived stem cells boost vascularization in grafted ovarian tissue by growth factor secretion and differentiation into endothelial cell lineages. Mol Hum Reprod. 2019;25:184-93. https://doi.org/10.1093/molehr/gaz008.

134. Manavella DD, Cacciottola L, Pommé S, Desmet CM, Jordan BF, Donnez J, et al. Two-step transplantation with adipose tissuederived stem cells increases follicle survival by enhancing vascularization in xenografted frozen-thawed human ovarian tissue. Hum Reprod. 2018;33:1107-16. https://doi.org/10.1093/humrep/ dey080.

135. Damous LL, Nakamuta JS, de Carvalho AETS, Carvalho KC, Soares JM Jr, de Jesus SM, et al. Scaffold-based delivery of adipose tissue-derived stem cells in rat frozen-thawed ovarian autografts: preliminary studies in a rat model. J Assist Reprod Genet. 2015;32:1285-94. https://doi.org/10.1007/s10815-015-0527-x.

136. Cho E, Kim YY, Noh K, Ku SY. A new possibility in fertility preservation: the artificial ovary. J Tissue Eng Regen Med. 2019;13:1294-315. https://doi.org/10.1002/term.2870.

137. Johnson J, Canning J, Kaneko T, Pru JK, Tilly JL. Germline stem cells and follicular renewal in the postnatal mammalian ovary. Nature. 2004;428:145-50. https://doi.org/10.1038/nature02316.

138. Laronda MM, Rutz AL, Xiao S, Whelan KA, Duncan FE, Roth $\mathrm{EW}$, et al. A bioprosthetic ovary created using $3 \mathrm{D}$ printed microporous scaffolds restores ovarian function in sterilized mice. Nat Commun. 2017;8. https://doi.org/10.1038/ncomms15261.

139. Luyckx V, Dolmans M-M, Vanacker J, Legat C, Fortuño Moya C, Donnez J, et al. A new step toward the artificial ovary: survival and proliferation of isolated murine follicles after autologous transplantation in a fibrin scaffold. Fertil Steril. 2014;101:1149 56. https://doi.org/10.1016/j.fertnstert.2013.12.025. 
140. Luyckx V, Dolmans M-M, Vanacker J, Scalercio SR, Donnez J, Amorim CA. First step in developing a 3D biodegradable fibrin scaffold for an artificial ovary. J Ovarian Res. 2013;6:83. https:// doi.org/10.1186/1757-2215-6-83.

141. Tilly JL, Telfer EE. Purification of germline stem cells from adult mammalian ovaries: a step closer towards control of the female biological clock? Mol Hum Reprod. 2009;15:393-8. https://doi. org/10.1093/molehr/gap036.

142. Vanacker J, Luyckx V, Dolmans M-M, Des Rieux A, Jaeger J, Van Langendonckt A, et al. Transplantation of an alginatematrigel matrix containing isolated ovarian cells: first step in developing a biodegradable scaffold to transplant isolated preantral follicles and ovarian cells. Biomaterials. 2012;33:6079-85. https:// doi.org/10.1016/j.biomaterials.2012.05.015.

143. White YAR, Woods DC, Takai Y, Ishihara O, Seki H, Tilly JL. Oocyte formation by mitotically active germ cells purified from ovaries of reproductive-age women. Nat Med. 2012;18:413-21. https://doi.org/10.1038/nm.2669.

144. Zhai J, Yao G, Dong F, Bu Z, Cheng Y, Sato Y, et al. In vitro activation of follicles and fresh tissue auto-transplantation in primary ovarian insufficiency patients. J Clin Endocrinol Metab. 2016;101:4405-12. https://doi.org/10.1210/jc.2016-1589.

145. Salama M, Woodruff TK. From bench to bedside: current developments and future possibilities of artificial human ovary to restore fertility. Acta Obstet Gynecol Scand. 2019;98:659-64. https://doi.org/10.1111/aogs.13552.

146. Chang EM, Song HS, Lee DR, Lee WS, Yoon TK. In vitromaturation of human oocytes: its role in infertility treatment and new possibilities. Clin Exp Reprod Med. 2014;41:416. https://doi.org/10.5653/cerm.2014.41.2.41.

147. Ellenbogen A, Shavit T, Shalom-Paz E. IVM results are comparable and may have advantages over standard IVF. Facts Views Vis Obgyn. 2014;6(2):77-80.

148. Hutt KJ, Albertini DF. Clinical applications and limitations of current ovarian stem cell research: a review. J Exp Clin Assist Reprod. 2006;3. https://doi.org/10.1186/1743-1050-3-6.

149. Martin J, Woods D, Tilly J. Implications and current limitations of oogenesis from female germline or oogonial stem cells in adult mammalian ovaries. Cells. 2019;8. https://doi.org/10.3390/ cells8020093.

150. Ozakpinar OB. Ovarian stem cells: from basic to clinical applications. World J Stem Cells. 2015;7:757-68. https://doi.org/10. 4252/wjsc.v7.i4.757.

151. Manavella DD, Cacciottola L, Desmet CM, Jordan BF, Donnez J, Amorim CA, et al. Adipose tissue-derived stem cells in a fibrin implant enhance neovascularization in a peritoneal grafting site: a potential way to improve ovarian tissue transplantation. Hum Reprod. 2018;33:270-9. https://doi.org/10.1093/humrep/dex374.

152. Cha SK, Shin DH, Kim BY, Yoon S-Y, Yoon TK, Lee WS, et al. Effect of human endothelial progenitor cell (EPC)- or mouse vascular endothelial growth factor-derived vessel formation on the survival of vitrified/warmed mouse ovarian grafts. Reprod Sci. 2014;21:859-68. https://doi.org/10.1177/1933719113518983.
153. Damous LL, Nakamuta JS, de Carvalho AETS, Soares-Jr JM, de Jesus SM, Krieger JE, et al. Adipose tissue-derived stem cell therapy in rat cryopreserved ovarian grafts. Stem Cell Res Ther. 2015;6:57. https://doi.org/10.1186/s13287-015-0068-3.

154. Xia X, Yin T, Yan J, Yan L, Jin C, Lu C, et al. Mesenchymal stem cells enhance angiogenesis and follicle survival in human cryopreserved ovarian cortex transplantation. Cell Transplant. 2015;24: 1999-2010. https://doi.org/10.3727/096368914x685267.

155. Donfack NJ, Alves KA, Araújo VR, Cordova A, Figueiredo JR, Smitz J, et al. Expectations and limitations of ovarian tissue transplantation. Zygote. 2017;25:391-403. https://doi.org/10.1017/ s0967199417000338.

156. Van Eyck A-S, Jordan BF, Gallez B, Heilier J-F, Van Langendonckt A, Donnez J. Electron paramagnetic resonance as a tool to evaluate human ovarian tissue reoxygenation after xenografting. Fertil Steril. 2009;92:374-81. https://doi.org/10.1016/j. fertnstert.2008.05.012.

157. Cacciottola L, Manavella DD, Amorim CA, Donnez J, Dolmans MM. In vivo characterization of metabolic activity and oxidative stress in grafted human ovarian tissue using microdialysis. Fertil Steril. 2018;110:534-544.e3. https://doi.org/10.1016/j.fertnstert. 2018.04.009.

158. des Rieux A, Ucakar B, BPK M, Colau D, Feron O, Carmeliet P, et al. 3D systems delivering VEGF to promote angiogenesis for tissue engineering. J Control Release. 2011. https://doi.org/10. 1016/j.jconrel.2010.11.028.

159. Dath C, Dethy A, Van Langendonckt A, Van Eyck AS, Amorim CA, Luyckx V, et al. Endothelial cells are essential for ovarian stromal tissue restructuring after xenotransplantation of isolated ovarian stromal cells. Hum Reprod. 2011;26:1431-9. https://doi. org/10.1093/humrep/der073.

160. Wang L, Ying Y-f, Ouyang Y-1, Wang J-f, Xu J. VEGF and bFGF increase survival of xenografted human ovarian tissue in an experimental rabbit model. J Assist Reprod Genet. 2013; https://doi. org/10.1007/s10815-013-0043-9

161. Li S-H, Hwu Y-M, Lu C-H, Chang H-H, Hsieh C-E, Lee R. VEGF and FGF2 improve revascularization, survival, and oocyte quality of cryopreserved, subcutaneously-transplanted mouse ovarian tissues. Int J Mol Sci. 2016;17. https://doi.org/10.3390/ ijms17081237.

162. Friedman O, Orvieto R, Fisch B, Felz C, Freud E, Ben-Haroush A, et al. Possible improvements in human ovarian grafting by various host and graft treatments. Hum Reprod. 2011;27:474-82. https:// doi.org/10.1093/humrep/der385.

163. Zhang $\mathrm{H}$, Yang Y, Ma W, Wu H, Zheng X, Hei C, et al. The revascularization and follicular survival of mouse ovarian grafts treated with FSH during cryopreservation by vitrification. CryoLetters. 2016;37(2):88-102.

Publisher's Note Springer Nature remains neutral with regard to jurisdictional claims in published maps and institutional affiliations. 